\title{
The Strategy Of APPlying Air Element For Brumbun SPring Tourism DEVELOPMENT DESIGN IN LAMONGAN
}

\section{Strategi Penerapan Unsur Angin Pada Desain Pengembangan Obyek Wisata Pemandian Air Panas Brumbun Di Lamongan}

\author{
Ahmad Yani $^{1 *}$, Wiwik Setyaningsih ${ }^{2}$, Avi Marlina ${ }^{3}$ \\ Prodi Arsitektur, Fakultas Teknik Universitas Sebelas Maret Surakarta ${ }^{1^{*}}$ \\ Ahmadyani_11_9e@yahoo.com \\ Prodi Arsitektur, Fakultas Teknik Universitas Sebelas Maret Surakarta ${ }^{2}$ \\ Prodi Arsitektur, Fakultas Teknik Universitas Sebelas Maret Surakarta ${ }^{3}$
}

\begin{abstract}
Brumbun hot springs which located in Lamongan regency has the potential of hot springs that emerge from the bowels of the earth so it will never be running out. The lack of attention from the government and communities make the condition of the tourist attractions of Brumbun hot springs becomes inaccessible and might causes damage for it's existing and natural facilities. Besides, the lack of activities variant also makes less visitors. With the support of the regency government through spatial plans, the purpose of designing a development of natural attractions can be done in order to improve the existence of a tourist attraction and the optimization of Brumbun's natural potential. The method used is descriptive qualitative with case study through stages of idea exploration, data collection observation, interview, and ecological architecture literature, then through analysis phase with precedent study and supporting data consisting of physical condition of tourist object and government regulations related to tourism object development. The result of the analysis is in the form of four applied elements of wind as an ecological architectural aspect of the building. It is roof pond with open pond system, nako rooster, vertical garden with structural media, and cross ventilation.
\end{abstract}

Keywords : Architecture, Air, Hot Springs, Ecology

\section{PENDAHULUAN}

Suatu potensi dari sebuah kawasan yang memiliki suatu keunikan yang tinggi dan khas, dapat menjadi sebuah pusaka budaya yang harus dilestarikan (Setyaningsih, 2016). Obyek wisata pemandian air panas Brumbun yang terletak di Kabupaten Lamongan memiliki potensi sumber air panas yang muncul dari dalam perut bumi sehingga tidak akan pernah habis. Berdasarkan aspek lokasi, obyek wisata berada di kawasan hutan yang dominan dengan nuansa alam, sehingga suasana yang tercipta adalah suasana yang tenang karena jauh dari kebisingan kota.

Saat ini kondisi obyek wisata pemandian air panas Brumbun mengalami kerusakan pada fasilitas eksisting, alam yang tidak terawat, dan kurangnya ragam kegiatan sehingga tidak dapat memberikan daya tarik pengunjung yang ingin mengunjungi obyek wisata tersebut. Hal ini bertolak balakang dengan potensi alam yang melimpah dan tidak pernah habis. Oleh karena itu, dibutuhkan sebuah pengembangan obyek wisata alam agar dapat meningkatkan eksistensi 
obyek wisata serta dapat mengoptimalkan potensi alam dari lingkungan tersebut.

Pengembangan obyek wisata pemandian air panas Brumbun ini juga didukung melalui kebijakan pengembangan yang tertuang dalam Rencana Induk Pengembangan Pariwisata (RIPP) Jawa Timur dan rencana pemerintah Kabupaten Lamongan yang akan meningkatkan promosi wisata pada seluruh obyek wisata di Lamongan (RTRW Kabupaten Lamongan, 2008).

Menurut Frick (1998) bumi, air, api, dan angin merupakan empat unsur yang dianggap sebagai awal terbentuknya hubungan antara bangunan dan juga lingkungan. Menurut Rahmawati (2014) unsur udara yang digunakan untuk bernafas oleh seluruh makhluk hidup sehingga ketercemaran udara harus dihindari untuk menjaga hubungan erat antara udara dan seluruh makhluk hidup yang ada. Dengan keadaan obyek wisata pemandian air panas Brumbun yang terletak di kawasan hutan, maka udara menjadi sebuah potensi karena angin yang berhembus akan mengakibatkan penurunan termal karena penyerapan panas oleh tumbuhan. Dengan adanya potensi pada udara maka dibutuhkan pengolahan udara di dalam bangunan untuk memberikan kenyamanan yang optimal bagi pengunjung obyek wisata.

Menurut Frick (1998) angin dan pengudaraan ruangan secara terus menerus mempersejuk iklim ruangan. Udara yang bergerak menghasilkan penyegaran terbaik karena dengan penyegaran tersebut terjadi proses penguapan yang dapat menurunkan suhu pada kulit manusia. Dengan demikian angin juga dapat dimanfaatkan untuk mengatur udara pada ruang. Bangunan yang memiliki desain akomodatif terhadap potensi lingkungan tropis dengan ciri khas matahari berlimpah dan kecepatan angin sepoi-sepoi, secara hipotesis dapat memberikan tingkat kenyamanan huni yang lebih baik (Yuliani ; Setyaningsih, 2018). Menurut Rahayu (2016) penyegaran udara di dalam ruang tergantung pada pertukaran udara yang berbeda berdasarkan tinggi di atas permukaan bumi dan rata atau tidaknya permukaan bumi. Hungerbühler (dalam Frick, 1998) menyatakan bahwa kamar keluarga dan kamar tidur membutuhkan sekurang-kurangnya 20 kali pertukaran udara dalam 1 jam, ruang sirkulasi minimal 10 kali, dapur minimal 100 kali, dan kamar mandi sebesar 40 kali penukaran udara dalam 1 jam.

Menurut Frick (1998) terdapat beberapa penerapan dalam perancangan sehingga dapat mengatur udara dari luar dan senantiasa masuk ke dalam bangunan. Beberapa penerapan tersebut antara lain:

a. Pengkondisian udara secara alami menggunakan sistem roof pond. Menggunakan media air untuk mengkondisikan udara secara alami. Air dapat mendinginkan udara dan juga menenangkan angin yang berhembus.

b. Roster merupakan lubang yang ditempatkan dengan baik pada dinding sehingga memungkinkan angin dapat berhembus atau masuk dalam bangunan.

c. Taman vertikal. Jendela atau bukaan berupa jendela maupun pintu dalam suatu bangunan tidak menjadi satu - satunya akses masuknya panas ke dalam bangunan. Udara panas dari luar bangunan juga dapat masuk dengan konduksi melalui dinding. Oleh karena itu, cara terbaik untuk menjaga kelembaban dinding adalah dengan penanaman pada dinding tersebut sehingga dapat mengusir panas sebelum terkonduksi ke dalam dinding.

d. Cross ventilation merupakan dua bukaan berupa jendela atau pintu yang letaknya saling berhadapan di dalam satu ruangan. Perbedaan tekanan pada kedua sisi bangunan akan menarik udara segar memasuki bangunan dari satu sisi dan mendorong udara pengap keluar ruangan dari sisi lain.

\section{METODE}

Metode penelitian yang digunakan yaitu metode deskriptif dan studi kasus dengan melalui empat tahapan. Tahapan pertama yaitu eksplorasi ide yang menemukan bahwa terdapat sebuah potensi sumber air panas yang terdapat di obyek wisata pemandian air panas Brumbun namun ternyata masih membutuhkan sebuah fasilitas penunjang untuk meningkatkan eksistensi yang ada dari potensi tersebut. 
Tahapan kedua yaitu pengumpulan data yang terdiri dari tiga sumber. Sumber pertama adalah observasi dan wawancara dengan pihak obyek wisata. Sumber kedua yaitu preseden yang dipilih berdasarkan prinsip kegiatan dan pendekatan arsitektur yang sesuai dengan konsep pengembangan yang akan dirancang. Sumber ketiga yaitu literatur yang mengambil dari referensi buku dan jurnal, yaitu "Pengantar Ilmu Pariwisata" oleh Yoeti (1996), "Dasardasar Eko-arsitektur" oleh Frick (1998), dan konsep dari jurnal yang membahas minimalisir dampak negatif dalam pembangunan sebuah kawasandengan judul "Low-ImpactDevelopment as an Implementation of the EcoGreen-Tourism Concept to Develop Kampung towards Sustainable City" oleh Setyaningsih (2015).

Tahapan ketiga yaitu analisis yang menggunakan 2 cara yaitu studi preseden dan interpretasi data. Analisis studi preseden dilakukan dengan cara menemukan kesesuaian antara prinsip dari teori unsur udara pada pendekatan arsitektur ekologis dengan dengan realita kondisi eksisting obyek wisata pemandian air panas. Sedangkan pada proses interpretasi data dilakukan dengan cara menafsirkan data dalam bentuk kata.

Tahapan terakhir yaitu perumusan strategi unsur udara pada desain pengembangan obyek wisata pemandian air panas. Dihasilkan 4 buah penerapan unsur udara pada bangunan, di antaranya adalah roof pond, roster, taman vertikal, dan ventilasi silang.

\section{HASIL DAN PEMBAHASAN}

Menurut Frick (1998) angin dan pengudaraan ruangan secara terus menerus mempersejuk iklim ruangan. Menurut Frick (1998) terdapat beberapa penerapan dalam perancangan sehingga dapat mengatur udara dari luar dapat senantiasa masuk ke dalam bangunan. Beberapa penerapan tersebut antara lain roof pond, roster, taman vertikal, dan ventilasi silang. Berikut adalah pembahasan mengenai penerapan unsur udara pada bangunan.

\subsection{Roof pond}

Roof pond merupakan atap yang di atasnya terdapat kolam air sebagai pengatur suhu pada bangunan (Mazria dalam Hossain, 2006). Sistem kolam air terdiri dari kolam yang ditampung dalam atap datar yang terbuat dari bahan semen, kemudian ditopang dengan dinding batu bata. Udara panas pada siang hari yang menuju bangunan akan diserap oleh air sehingga yang masuk ke dalam bangunan adalah udara yang dingin. Panas matahari yang tersimpan dalam air tersebut kemudian akan dilepaskan ketika malam hari.

Berdasarkan bagaimana air terkandung di atap, kolam air dapat diklasifikasikan dalam tiga jenis: atap kering, atap basah, dan atap terbuka.

Dalam sistem kolam air atap kering air disimpan di dalam kantong plastik transparan dan tidak beredar masuk dan keluar dari kantong kapan saja. Kantung-kantung air tersebar seluruh atap dan didukung oleh langitlangit struktural. Lapisan logam yang sangat konduktif umumnya digunakan sebagai plafon struktural. Sistem atap kering mungkin juga terdiri dari panel insulasi bergerak yang menutupi kantong air pada waktu yang tepat selama keduanya mode pemanasan dan pendinginan operasi. Atap kering mungkin atau mungkin tidak berkaca dan dapat diadaptasi untuk aplikasi pendinginan dan pemanasan.

Dalam sistem atap yang basah, air terkandung dalam kantong transparan yang dibanjiri atau disemprot dengan air sehingga permukaan kantong tetap basah. Strategi ini diterapkan dengan meningkatkan kinerja pendinginan dari atap kemudian terjadi pendinginan secara evaporative sehingga sistem ini paling sesuai untuk tujuan pendinginan. Sistem pendinginan dapat diadaptasi untuk fungsi pemanasan, dengan menguras air yang tergenang atau dengan disemprot.

Sistem atap terbuka hanya digunakan untuk aplikasi pendinginan di mana air disimpan dan untuk ditampilkan sebagai sebuah kolam yang terbuka. Akan tetapi kurangnya perlindungan termal selama mode pemanasan membuat konfigurasi seperti itu cukup rentan terhadap kehilangan panas yang banyak ketika malam hari.

Dari ketiga jenis sistem kolam air yang telah dijelaskan, maka jenis kolam air akan dipilih yaitu kolam air dengan sistem terbuka. Hal ini cukup sesuai dengan fungsi bangunan sebagai 
sebuah obyek wisata sehingga sistem kolam air juga harus berfungsi sebagai sebuah atraksi wisata yang terdapat dalam sebuah bangunan.

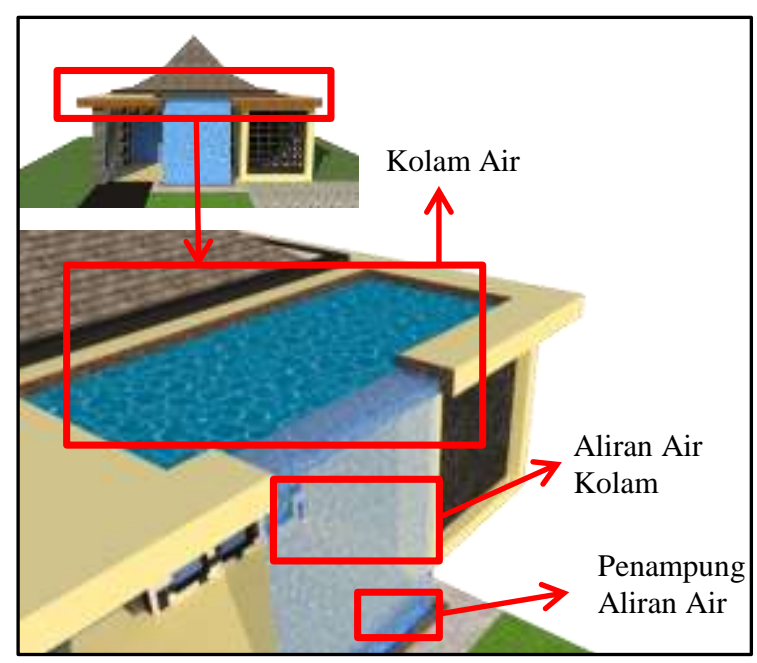

Gambar 1. Penerapan Kolam Air pada Atap Bangunan

Air yang mengalir dari kolam akan diterima oleh penampung yang kemudian akan mengalir dan dipompa kembali menuju atap sehingga kolam air juga dapat menjadi sebuah atraksi dalam bangunan (lihat pada Gambar 1).

Sistem ini dapat diterapkan pada bangunan dengan intensitas penggunaan yang tinggi. Penerapan kolam air akan diterapkan pada bangunan cottage dan juga pengelola dikarenakan jumlah kegiatan dan intensitas penggunaan ruang lebih tinggi daripada kegiatan yang lainnya.

\subsection{Roster}

Menurut Afari (2015) fungsi utama dari roster adalah sebagai lubang dinding untuk menciptakan sistem sirkulasi udara yang lebih maksimal dalam ruangan. Selain itu, roster juga bisa digunakan sebagai ornamen pada bangunan agar lebih menarik dan juga dapat diaplikasikan sebagai pengganti pagar.

Roster dibuat dari berbagai macam bahan, di antaranya adalah beton, semen dan pasir yang dipadatkan, keramik, batako, dan tanah liat. Roster yang terbuat dari batako memiliki kualitas yang lebih bagus dan kuat, akan tetapi apabila dilihat dari tampilannya, kurang menarik dibandingkan dengan roster yang terbuat dari tanah liat. Sedangkan untuk roster tanah liat, tampilannya lebih menarik, akan tetapi tidak begitu kuat apabila dibandingkan dengan roster batako.

Selain dari bahan tersebut, terdapat juga jenis roster yang terbuat dari bahan beton. Roster ini disebut sebagai roster nako, yaitu roster yang memiliki sirip dengan sudut kemiringan tertentu sehingga percikan air hujan tidak bisa masuk ke dalam ruangan tanpa mengurangi fungsi roster sebagai ventilasi ruangan. Kebanyakan roster nako diaplikasikan pada bangunan gudang atau pabrik.

Dalam proses pemasangannya roster dapat disusun secara selang-seling dan direkatkan menggunakan semen. Selain menggunakan perekat semen, roster hanya perlu dikuatkan menggunakan tambahan pelat besi. Pelat besi ini memiliki fungsi adalah untuk membuat roster bertambah kaku dan tidak mudah roboh apabila terdorong angin atau tersenggol. Konstruksi roster biasanya tidak menggunakan tiang maupun balok. Dinding roster hanya bertumpu pada sloof yang menyalurkan beban dan kemudian mengikat pondasi di dalam tanah.

Kelebihan pegaplikasian dinding roster dalam bangunan di antaranya adalah (1) udara dalam ruangan menjadi sejuk karena dapat tersirkulasi dengan baik, (2) cahaya matahari dari luar dapat masuk ke dalam ruangan dengan maksimal, (3) motif yang menarik membuat roster dapat dijadikan sebagai unsur dekorasi, (4) roster yang berfungsi sebagai dinding namun dapat juga berfungsi sebagai ventilasi udara.

Dalam pengaplikasian dinding roster perlu diperhatikan jumlah intesitas cahaya matahari yang masuk dikarenakan lubang yang cukup banyak. Apabila berhadapan secara langsung dengan arah datangnya sinar matahari, ruang yang berada di dalam roster menjadi kurang nyaman dikarenakan panas. Selain itu, roster tidak dapat menahan beban yang banyak sehingga tidak dapat dijadikan sebagai dinding utama. Pemasangan roster sebagai eksterior juga dapat mengakibatkan masuknya debu dari luar yang terbawa angin ke dalam rumah.

Dengan banyaknya jenis roster yang ada maka yang akan diaplikasikan pada desain pengembangan obyek wisata adalah jenis roster nako. Roster ini akan diaplikasikan pada ruang yang bersifat publik seperti ruang keluarga pada 
cottage, ruang rapat pada area pengelola, area istirahat pada kegiatan outbound, dan juga pada mushola.

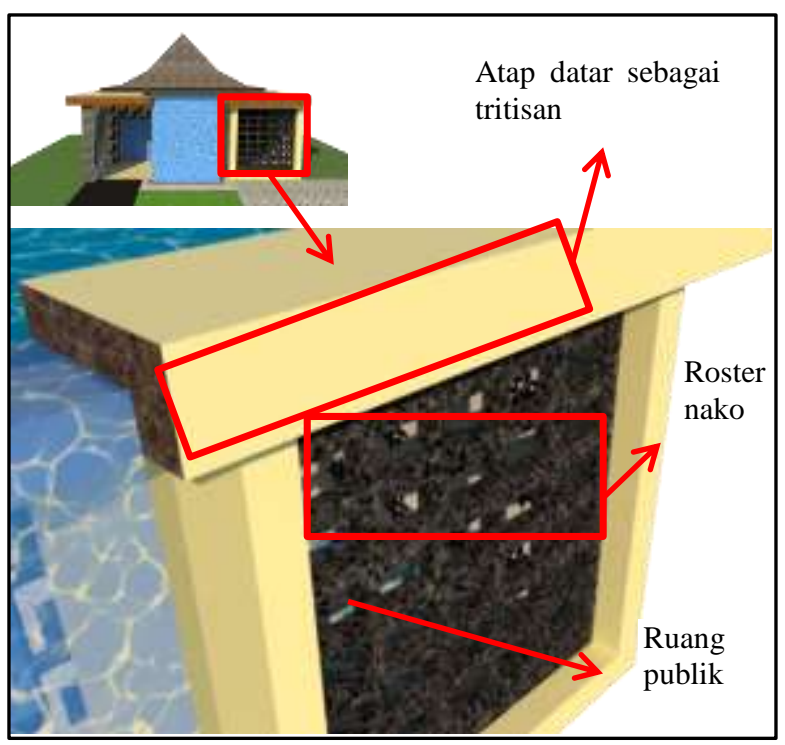

Gambar 2. Aplikasi Roster Jenis Nako pada Bangunan

Letak pemasangan roster juga harus memiliki pola di mana akan lebih banyak diaplikasikan pada arah yang sejajar dengan pergerakan angin (lihat pada Gambar 2). Pada obyek wisata pemandian air panas Brumbun, angin bergerak dari arah selatan ke utara sehingga pemasangan roster akan lebih dominan pada arah tersebut.

\subsection{Taman Vertikal}

Menurut Martin (2013) taman vertikal adalah sebuah metode dalam bercocok tanam dengan menggunakan lahan yang sempit dan terbatas dengan menggunakan dinding atau ruang secara vertikal dengan menutupinya dengan tumbuhan yang tumbuh di atas media tanam. Dinding ini bisa ditempatkan di dalam maupun luar ruangan, melekat atau pun terpisah dari dinding yang sudah ada dan bisa dalam berbagai ukuran.

Menurut Ong (2003) tumbuhan pada taman vertikal berfungsi untuk menurunkan temperatur bangunan, terutama ketika ditanam di dinding yang menyerap cahaya matahari paling banyak, sehingga kebun vertikal berfungsi sebagai insulasi. Tumbuhan akan menyerap panas, dan dengan proses transpirasi tumbuhan akan menyerap air dan menguapkan air dari stomata.
Taman vertikal juga dapat menjadi salah satu cara dalam melakukan pertanian urban dan membentuk karya seni di dinding yang tidak terpakai. Beberapa pembahasan terdapat istilah yang disebut dengan "dinding aktif", di mana dinding ini menyerap dan menghembuskan udara melalui bagian tubuh tumbuhan dan media tanam ke dinding sehingga dapat berfungsi sebagai sistem HVAC dari bangunan tersebut. Dinding aktif ini dapat menggantikan sebagian komponen penyaring udara.

Kebun vertikal menurut Martin (2013) dapat dikategorikan menjadi 3 berdasarkan jenis media tanamnya, antara lain media renggang, media lapisan berongga (mat) dan media struktural.

Jenis media tanah gembur atau renggang biasanya dikemas dalam susunan rak atau bungkusan dan dipasangkan di dinding. Sistem ini membutuhkan pergantian media tanam setidaknya setahun sekali apabila diletakkan di luar ruangan dan kira-kira setiap dua tahun sekali apabila diletakkan di dalam ruangan. Sistem tanah gembur ini tidak sesuai untuk daerah yang sering dilanda gempa. Proses perbaikan media tanam hanya dilakukan dengan mengisi ulang tanah ke dalam lubang di dinding, akan tetapi proses perbaikan tersebut cukup sulit untuk dilakukan.

Sistem tanah gembur ini sebaiknya tidak digunakan di area yang banyak terjadi interaksi publik dikarenakan ketidakrapian dari segi visual dan tanah yang terus berkurang sedikit demi sedikit. Sistem ini mudah terbang oleh hujan berangin atau angin besar, sehingga sebaiknya pengaplikasian taman jenis ini tidak memiliki tinggi lebih dari 8 kaki. Akan tetapi terdapat beberapa sistem yang dapat menyelesaikan masalah erosi tanah gembur ini dengan menggunakan shielding systems untuk menahan media di antara dinding hijau ketika tanah yang bergerak.

Dalam sistem ini, tanaman tetap dapat bisa mempertahankan dirinya dalam tanah yang menggembur, oleh karena itu tanaman perlu diamankan dengan sistem yang mencegahnya untuk jatuh dari dinding. Sistem tanah gembur tanpa erosi ini cocok untuk tukang kebun rumahan yang jarang menanam ulang dari musim ke musim atau dari tahun ke tahun. 
Sistem tanah gembur dengan erosi cocok untuk semua aplikasi dinding hijau.

Media mat memiliki jenis alas yang sistem susunannya cenderung berupa serat sabut atau tikar. Media alas ini cukup tipis, bahkan dalam beberapa lapisan, dengan demikian tidak dapat mendukung sistem akar yang hidup pada tanaman dewasa selama lebih dari tiga sampai lima tahun sebelum akar menyalip tikar dan air tidak mampu memadai melalui sumbu tikar, serta dapat meminimalisir dampak negatif dari aliran air yang ada (Setyaningsih, 2015). Metode perbaikan media tanam dari sistem ini yaitu dengan menggantikan sebagian besar dari sistem pada suatu waktu dengan memotong tikar keluar dari dinding dan menggantinya dengan yang baru. Sistem ini paling baik digunakan pada interior bangunan dan merupakan pilihan yang baik di daerah dengan aktivitas seismik yang rendah dan tanaman kecil yang tidak akan tumbuh dengan berat yang bisa merobek tikar terpisah dengan berat badan mereka sendiri dari waktu ke waktu.

Sistem mat ini juga tidak begitu efisien dan sering memerlukan irigasi konstan karena sifat tipis menengah dan ketidakmampuannya untuk menahan air dan menyediakan penyangga bagi akar tanaman. Inefisiensi ini sering membutuhkan bahwa sistem ini memiliki air sistem re-sirkulasi dimasukkan ke dalam tempat dengan biaya tambahan. Media mat ini lebih cocok untuk instalasi kecil tidak lebih dari delapan meter sehingga proses perbaikan media mudah untuk diselesaikan.

Media struktural adalah media tanam yang berbentuk blok yang tidak longgar dan tidak berongga, akan tetapi media struktural menggabungkan keunggulan dari kedua media tersebut, dalam bentuk blok yang dapat di produksi menjadi berbagai ukuran, bentuk, dan ketebalan. Media struktural memiliki beberapa keunggulan, di antaranya media ini tidak akan rusak sampai berusia 10 atau 15 tahun. Media ini dapat menampung sejumlah air yang tergantung berdasarkan jenis tanaman yang dipilih, selain itu juga memiliki $\mathrm{pH}$ dan elektrokonduktivitas yang sesuai untuk tanaman, dan media ini mudah untuk dirawat atau diganti.

Media ini adalah pilihan yang paling kuat di dinding untuk diterapkan di bagian eksterior dan interior bangunan. Mereka juga pilihan terbaik di daerah di mana kekuatan angin, aktivitas seismik, atau ketinggian perlu ditangani dalam desain. Media struktural lebih unggul daripada media lain untuk umur panjang mereka dan tingkat kinerja yang tinggi dalam berbagai situasi. Tergantung pada jenisnya, media struktural cenderung lebih mahal ketika pemasangan, tetapi biaya yang lebih murah untuk dikelola.

Jenis taman vertikal yang dapat diaplikasikan pada desain bangunan adalah taman vertikal dengan media struktural. Pemilihan jenis taman vertikal ini dikarenakan lebih kuat dan memiliki kinerja yang lebih baik dari jenis media yang lainnya (lihat pada Gambar 3).

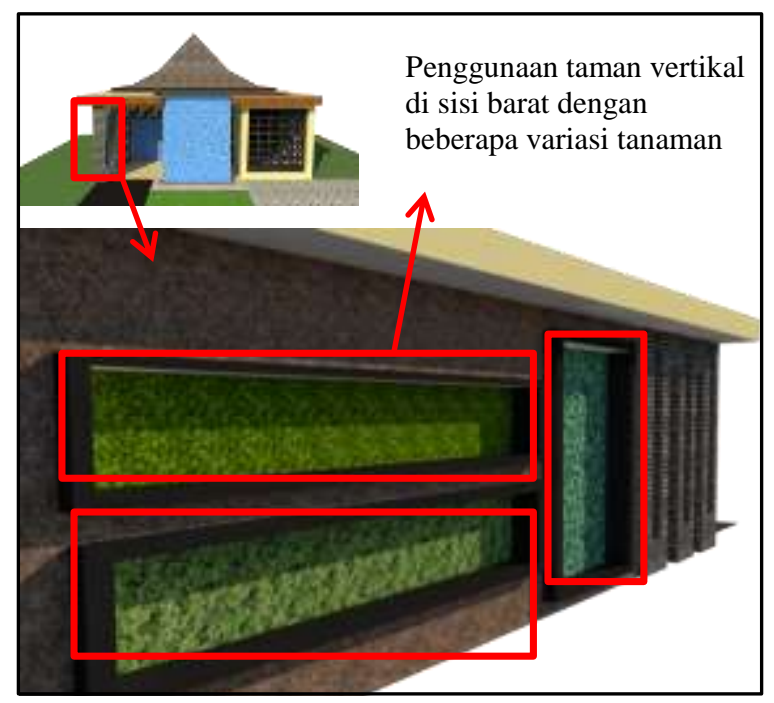

Gambar 3. Penerapan Taman Vertikal pada Eksterior Bangunan

Pemasangan taman vertikal ini akan diaplikasikan pada seluruh bangunan. Pengaplikasian taman vertikal ini akan diarahkan pada arah sinar matahari sore, sehingga panas yang mengenai bangunan akan diserap oleh tumbuhan dan ketika masuk ke dalam bangunan akan bertransformasi menjadi udara dingin yang juga akan berdampak pada ruang yang ada di dalamnya.

\subsection{Ventilasi Silang}

Metode eksperimen oleh Stavrakakis (2007) mengenai ventilasi silang telah dikembangkan untuk menentukan pola aliran udara dan lingkungan termal dalam ruangan. Dari penelitian tersebut dihasilkan bahwa ventilasi silang membantu menarik udara dingin dan 
mendorong udara panas yang basi atau stagnan, keluar dari bangunan mana pun.

Penerapan ventilasi silang pada bangunan memiliki beberapa keunggulan, yaitu bangunan akan mendapatkan kondisi termal yang dingin sehingga tidak memerlukan sistem pendingin secara buatan, selain itu juga membantu mencegah kelebihan kelembaban dan panas yang terdapat di rongga langit-langit pada ruang.

Menurut Frick (1998), ventilasi silang pada bangunan memiliki beberapa kriteria sehingga angin dapat selalu masuk ke dalam bangunan. Kriteria tersebut di antaranya adalah kondisi tekanan, pergerakan udara, letak lubang masuk udara, dan kecepatan udara.

Kondisi tekanan yang berbeda pada kedua sisi lubang masuk aliran udara, akan membelok mencari jalan yang lain. Hal ini yang berarti bahwa letak sisi bukaan atau lubang masuk udara dalam pembuatan sebuah denah harus memiliki orientasi yang berbeda untuk mengubah kondisi tekanan masing-masing bukaan (lihat pada Gambar 4).

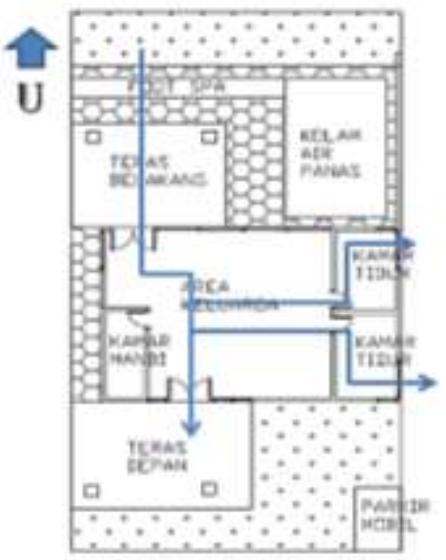

Gambar 4. Penerapan Sistem Ventilasi Silang pada Denah Cottage

Pergerakan atau aliran udara bergerak berdasarkan pada ketinggian. Pada gedung yang bertingkat, pada lantai satu angin akan bergerak hingga rongga bawah ruang, sedangkan pada gedung yang bertingkat di ruangan tingkat atas aliran udara bergerak dekat pada langit-langit.

Penerapan ventilasi silang pada desain pengembangan obyek wisata pemandian air panas akan diterapkan pada seluruh bangunan, kecuali bangunan yang terletak pada zona servis (lihat pada Gambar 5).

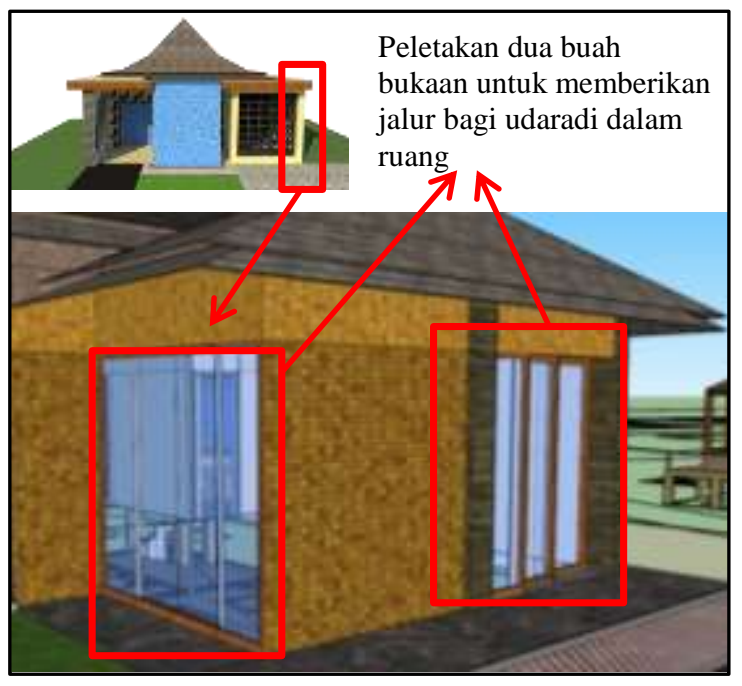

Gambar 5. Penerapan Sistem Ventilasi Silang pada Bangunan

Pengaplikasian ventilasi silang akan diarahkan sesuai dengan arah angin. Pada obyek wisata pemandian air panas Brumbun, angin bergerak dari arah selatan ke utara sehingga pemasangan ventilasi silang akan lebih dominan pada arah tersebut.

\section{KESIMPULAN}

Pembahasan mengenai penerapan unsur udara pada pengembangan obyek wisata pemandian air panas Brumbun menghasilkan 4 buah penerapan desain:

a. Penerapan roofpond atau kolam air dengan sistem terbuka yang diterapkan pada bangunan dengan intensitas penggunaan yang tinggi. Penerapan kolam air akan diterapkan pada bangunan cottage dan juga pengelola dikarenakan jumlah kegiatan dan intensitas penggunaan ruang lebih tinggi daripada kegiatan yang lainnya.

b. Pengaplikasian roster jenis nako pada ruang yang bersifat publik seperti ruang keluarga pada cottage, dan juga pada mushola. Letak pemasangan roster juga memiliki pola di mana akan lebih banyak diaplikasikan pada arah yang sejajar dengan pergerakan angin, yaitu sisi utara dan selatan.

c. Aplikasi taman vertikal pada desain bangunan dengan menggunakan media 
struktural. Pemasangan taman vertikal ini akan diaplikasikan pada seluruh bangunan. untuk pengaplikasian taman vertikal ini akan diarahkan pada arah sinar matahari sore, yaitu arah barat.

d. Penerapan ventilasi silang pada desain pengembangan obyek wisata pemandian air panas pada seluruh bangunan, kecuali bangunan yang terletak pada zona servis. Pengaplikasian ventilasi silang akan diarahkan sesuai dengan arah angin, yaitu arah utara dan selatan.

\section{REFERENSI}

Afari, Shabrina. (2015, September 2). Dinding Rooster. Arsitag.

Dinas Pekerjaan Umum Kabupaten Lamongan. (2008). Rencana Tata Ruang dan Wilayah Kabupaten Lamongan.

Frick, Heinz. (1998). Dasar-dasar Ekoarsitektur. Yogyakarta: Penerbit Kanisius (Anggota IKAPI).

Hossain, Afzal. (2006). Development And Validation Of Heat Transfer Model To Predict Indoor Air Temperatures In Roofpond Buildings. Bangladesh University of Engineering And Technology.

Martin, Eric. (2013). Calderon Fetes G-20 As Sun Sets On Mexico Ruling Party. Bloomberg Lp.

Monroe, James Stewart. (2005). Physical Geology: Exploring the Earth. Thomson Brooks/ Cole.

Ong, B. (2003). Green Plot Ratio: An Ecological Measure For Architecture And Urban Planning. Sciencedirect.

Rahayu, Karlina Hangesti. (2016). Agrowisata Kopi Di Kledung Kabupaten Temanggung Dengan Pendekatan Arsitektur Ekologi. Arsitektura, 14.

Rahmawati, Maya. (2014). Pengembangan Agrowisata Pantai Glagah Kabupaten Kulon Progo Dengan Pendekatan Arsitektur Ekologi. Arsitektura, 12.

Setyaningsih, Wiwik. (2015). Low-ImpactDevelopment as an Implementation of the Eco-Green- Tourism Concept to Develop Kampung towards Sustainable City. Procedia - Social and Behavioral Sciences ElsevierScience Direct, 179 (2015) 109 117.

Setyaningsih, Wiwik. (2016). Urban Heritage Towards Creative-Based Tourism In The Urban Settlement Of Kauman Surakarta. Elsevier, 227.

Stavrakakis. (2007). Natural cross-ventilation in buildings: Building-scale experiments, numerical simulation and thermal comfort evaluation. Elsevier.

Yoeti, Oka A. 1996. Pengantar Ilmu Pariwisata. Bandung: Angkasa.

Yuliani, Sri; Setyaningsih, Wiwik. (2018). The Impact of Thermal Performance on The Roof Surface to Energy Efficient of High-Rise Building in The Tropical Region.Arsitektura, 16. 